\title{
REAL CONVERGENCE IN EU: IS THERE A DIFFERENCE BETWEEN THE EFFECTS OF THE PANDEMIC AND THE GLOBAL ECONOMIC CRISIS?
}

\author{
Aleksandra Fedajev ${ }^{\mathrm{a}}$ (D), Magdalena Radulescu ${ }^{\mathrm{b}}$ (D), \\ Ana-Gabriela Babuceac (iD, Vladimir Mihajlovic ${ }^{d}$
}

\begin{abstract}
This paper aims to shed some light on the real convergence process among EU economies in the context of the COVID-19 pandemic crisis in comparison to the real convergence in 2008, when the last financial crisis erupted. According to entropy method results, the most pronounced difference between effects of the current pandemic and the global financial crisis are registered in the unemployment rate, while the difference in the current account balance and GDP per capita are much less noticeable. The results of the entropy method also suggest that the greatest difference among EU economies in 2020 is registered in the current account deficits; a slightly lower difference is registered in the unemployment rate, while the divergence in GDP is much less pronounced. To explain the results of the entropy method, a hierarchical cluster analysis is performed and three clusters are derived. Based on the identified characteristics of the derived clusters, some policy recommendations for overcoming the current crisis are defined.
\end{abstract}

Keywords: Pandemic crisis, convergence, EU, entropy method, cluster analysis

JEL Classification: R12, E61, E63, H12

\section{Introduction}

The global economic and financial crisis, which began on the US financial market in 2007 and quickly spread around the world in 2008, had a significant negative impact on EU

a University of Belgrade, Technical Faculty in Bor, Republic of Serbia E-mail: afedajev@ttbor.bg.ac.rs

b University of Pitesti, Faculty of Economic Sciences, Romania E-mail: magdalena.radulescu@upit.ro and “Lucian Blaga” University of Sibiu, Romania

c Constantin Brancusi University of Targu Jiu, Faculty of Economics, Romania E-mail: gabibabucea@gmail.com (corresponding author)

d University of Kragujevac, Faculty of Economics, Republic of Serbia E-mail: vmihajlovic@kg.ac.rs

Conflict of interest statement: On behalf of all the authors, the corresponding author states that there is no conflict of interest. 
economies, especially on the then New Members States (NMS), such as the Central and Eastern European (CEE) countries and the Baltic States. The circumstances of the economic crisis that followed were different across EU countries, resulting in real divergence in the EU after the significant catching-up process of the NMS. In contrast to the global downturn in 2008, which mostly affected underdeveloped and developing countries, the pandemic mainly affected developed countries. Accordingly, it is expected that the EU's most developed economies will diverge as a result of the current crisis (Bisciari et al., 2020). While a structural shock generated by the crisis on the financial markets in 2008, which spilt over into the real sector, the current pandemic crisis represents a sudden stop of economic activity and represents both a supply chain disruption crisis and a crisis caused by a demand shock.

The current pandemic crisis caused a remarkable drop in economic activity, employment and trade flow due to its comprehensiveness (considering that it impacted all EU economies), its dynamics (in a few weeks, millions of employees had been fired), and its intensity (it hit all EU economies with an unprecedented economic downturn) (Arce et al., 2020). The differences in economic structure, available resources, economic heritage and other specificities resulted in increased divergence in economic growth across EU economies. The highly open economies, relying more on tourism, faced a greater drop in economic activity in 2020 (König and Winkler, 2020). In addition to a significant decline in economic activity, the lockdown and the travel restrictions resulted in a temporary closure of many jobs. As the diversity of labour markets across EU economies is still present, the unemployment rates are expected to be considerably different across EU economies in the future. The pandemic crisis is also characterized by tight restrictions on foreign trade and movement of goods, services, capital, labour, technology, data and information, and it is expected that these restrictions will be present for a long time. Such a situation is present especially in the pharmaceutical, medical equipment and food sectors, where governments impose export restrictions and other protectionist measures in response to the crisis. As the COVID-19 pandemic has mostly affected developed economies and is mainly a demand shock, imports will fall mostly in those countries. Considering that the pandemic crisis has affected three main aspects of real convergence (economic growth, employment, and trade flows), it is expected to have a severe effect on real convergence in the EU.

Since ensuring real convergence is a key precondition for achieving the long-term sustainability of the EU, this paper aims to present a comprehensive analysis of real convergence among EU countries based on three most commonly used real convergence indicators (GDP per capita PPP, unemployment rate and current account balance) at two moments that have influenced the EU convergence greatly: 2008 (when the global financial 
and economic crisis spilt over all EU economies) and 2020 (when the COVID-19 pandemic crisis induced a sudden and dramatic stop in economic activities). The combined analysis methods primarily represent this paper's novelty - both entropy method and cluster analysis were employed to investigate the real convergence among EU countries. In contrast to other real convergence research based on one indicator, different aspects of real convergence are considered in this paper, considering that three indicators are used for real convergence measurement. Finally, this is one of the rare studies that compare the effects of the global financial crisis and the current pandemic crisis on real convergence in the EU.

\section{Literature Review}

The survival of the EU relies on responding to the serious financial problems caused by the COVID-19 pandemic and resolving the long-term structural issues that have led to growing disparities among its members. This is why research of real convergence occupies a special place in the literature on the development of European integration. Most of the papers in this area have focused on the analysis of one real convergence indicator (Simionescu-Bratu, 2014; Albu, 2012; Alcidi et al., 2018). However, after the emergence of the global financial crisis, the number of papers dealing with real convergence issues has been growing.

After the global financial crisis, most of the papers have focused on the catching-up process of NMS and especially CEE and SEE countries. Cieslik and Wcislik (2020) investigated the real GDP per capita convergence between the CEE-8 and their catching-up with the old EU-15. They did not find clear evidence for catching-up of the CEE-8 economies with the EU-15, although the CEE-8 economies had undergone profound changes due to the transition process and EU accession. Their results suggested that there is also a weak, but overall relative convergence within the group of the CEE-8 economies. Młynarzewska-Borowiec (2017) studied the real convergence among the EU countries in 2000-2014 and demonstrated a real convergence of GDP per capita PPP and total labour force for EU-27 (except Croatia). The results pointed out that the convergence was much stronger among the NMS than for the EU-27 as a whole, while less developed countries (Southern European countries) did not manage to catch up with the advanced European countries. They concluded that the technological channel, increase in technology levels, and intensive technology transfer between countries are the driving force of the converging process in the European Union.

Durkalic et al. (2019) analysedanalysed the real convergence among EU-28 countries in 2004-2016 using the entropy method. Their results showed that the greatest differences 
among EU members exist in labour productivity (expressed as GDP per worker). After the global economic crisis, the divergence in the unemployment rate increased due to the different impacts of the crisis across EU economies and implementation of different measures. The crisis indicated that significant imbalances are still present on the labour market, both in the NMS and in some OMS. The CEE economies lacked capacities for successful implementation of labour policy due to their inheritance from real socialism. Some OMS, such as Greece, Spain, Italy and Portugal, had problems overcoming the effects of the crisis on their labour markets. The differences in GDP per capita PPP did not change a lot as a result of the crisis.

A number of papers dealing with the convergence process within a group of EMU countries were published after the sovereign debt crisis. So, Ferreiro et al. (2017) detected a significant divergence process in real GDP per capita and the balance on current transactions, thus exacerbating the differences present before the formation of the EMU. They also emphasized that the global financial crisis resulted in increased divergence in many macroeconomic performance indicators, generating the risk of a higher diversity among EMU members if the crisis became chronic/endemic or caused structural imbalances.

Diaz del Hoyo et al. (2017) pointed out that although the promoters of the single currency area had expected that joining the Eurozone would enhance the convergence among the member countries, this goal was not accomplished. Moreover, some countries with low incomes did not succeed in reducing the disparities or even started to diverge, such as Spain and Greece. Mayer and Schnabl (2020) emphasized that the coronavirus crisis had caused new distress in the EMU, as the southern EMU countries had been hit harder than the northern countries. Southern EMU members rely significantly on tourism and have a higher share of small and medium-sized enterprises than the northern ones, their competitiveness declining even further. Thus, the gap in real GDP between northern and southern countries, exemplified by Germany and Italy, increased significantly in 2020.

The results obtained by Coutinho and Turrini (2020) indicated that the global financial crisis in 2008 was followed by a reappraisal of risk and a sudden withdrawal of capital from the periphery of the EMU. The contraction in domestic demand was caused by sudden stops in current accounts resulting in a reversal in the convergence process. They suggest that countries that had been the first to adopt the euro had exhibited relatively weak convergence even before the global financial crisis. The divergence among those countries could be partly explained by relatively low dispersion in GDP per capita across this group of countries and partly by existing differences in total factor productivity. They also emphasize that macroeconomic imbalances accumulated during the pre-crisis period, such as high private and government debt and strong growth in the non-tradable sector, resulted in lower convergence, especially in the EMU. 
Malliaris and Malliaris (2020) focused on the first 20 years after the introduction of the euro, from 1999 to 2019, and they divided that period into two approximate decades to analyse the trend of three indicators: the real GDP quarterly growth, the real per capita GDP changes and unemployment. They concluded that the underperformance of the EU is more evident during the second decade due to the global financial crisis. Greece, Ireland, Italy, Portugal and Spain borrowed heavily in the period 2000-2007 from banks in Germany, France and the Netherlands, which hampered their growth with the emergence of a great financial crisis, and their economic imbalances are still present.

Boltho (2020) concluded that the EMU had not reduced GDP per capita PPP disparities among the 12 Western European economies. GDP per capita PPP between Southern and Northern Eurozone members has diverged since the Eurozone was created. $\mathrm{He}$ then investigated whether something similar had occurred in the five Eastern European countries, Estonia, Latvia, Lithuania, Slovakia and Slovenia. The results pointed out that the overall developments in Eastern Europe were different and led to convergence rather than divergence. One of the main factors for such a trend was Eastern Europe's relatively high levels of institutional quality, a politically motivated determination to anchor these countries to the West, and, possibly, the heritage from the previous period.

Generally observed, the previous literature has suggested that the global financial crisis has led to some divergence among EU countries. However, differences also result from institutional divergence and some inherited factors that are still present and influence the current crisis.

\section{Data and Methodology}

Keeping in mind that the paper aims to investigate the future differences among EU countries caused by the COVID-19 pandemic, data on some real convergence indicators have been used. They are analysedanalysed using the entropy method and cluster analysis.

\subsection{Data}

International institutions have published projections of some indicators for 2020 to give a rough picture of future trends in the pandemic crisis conditions. At the moment, these indicators are the most accurate and realistic (because they are calculated based on the appropriate set of data from national statistical offices). One of the international institutions that published its projections for 2020 most recently is the International Monetary Fund. Table 1 presents the IMF indicators of real convergence considered in this paper. 
Table 1: IMF real convergence indicators

\begin{tabular}{l|l|l}
\hline \begin{tabular}{l} 
Indicator \\
\multicolumn{3}{|c|}{ Real convergence indicators }
\end{tabular} & \multicolumn{1}{c}{ Source } \\
\hline $\begin{array}{l}\text { Gross domestic product per } \\
\text { capita, current prices, pur- } \\
\text { chasing power parity (in 000) }\end{array}$ & $\begin{array}{l}\text { GDP per capita } \\
\text { (GDP) }\end{array}$ & $\begin{array}{l}\text { World Economic Outlook Database (April 2020 } \\
\text { Edition), https://www.imf.org/external/pubs/ft/ } \\
\text { weo/2020/01/weodata/index.aspx }\end{array}$ \\
\hline $\begin{array}{l}\text { The unemployment rate, } \\
\text { percent of total labour force }\end{array}$ & $\begin{array}{l}\text { Unemployment } \\
\text { (UNEMP) }\end{array}$ & $\begin{array}{l}\text { World Economic Outlook Database (April 2020 } \\
\text { Edition), https://www.imf.org/external/pubs/ft/ } \\
\text { weo/2020/01/weodata/index.aspx }\end{array}$ \\
\hline $\begin{array}{l}\text { Current account balance, } \\
\text { percent of GDP }\end{array}$ & $\begin{array}{l}\text { Current account } \\
\text { balance (CAB) }\end{array}$ & $\begin{array}{l}\text { World Economic Outlook Database (April 2020 } \\
\text { Edition), https://www.imf.org/external/pubs/ft/ } \\
\text { weo/2020/01/weodata/index.aspx }\end{array}$ \\
\hline
\end{tabular}

Source: Elaborated by the authors

Although there are more indicators of real convergence in existing literature, such as GDP per worker and gross fixed capital formation, the considered indicators are now available and represent the most recent update of macroeconomic projections for all EU countries.

\subsection{Methodology}

In this paper, the entropy method is used to measure differences among EU countries according to considered indicators and cluster analysis to identify an appropriate group of EU countries with similar macroeconomic situations.

\subsubsection{Entropy method}

The real convergence among EU economies in this paper is measured by applying the methodology used by Czyz and Hauke (2015). They used the entropy method to analyse the divergence in the development of regions in Poland in the period 2005-2012. To calculate the differences in economic development among Poland's regions, they applied the Shannon entropy index. Having in mind that the EU represents regional integration focused on achieving harmonized development and cohesion, the authors concluded that a similar approach could be applied at the EU level. Identification of gaps in real convergence indicators can improve the information basis for creating efficient policy implications to prevent the spreading economic crisis caused by the COVID-19 pandemic in the EU and, accordingly, to reduce its impact on the convergence process. 
Some adjustments in data on nominal indicators are necessary to apply the entropy method according to the approach of Czyz and Hauke (2015). Taking into account that the current account balance can take negative values and that only a positive real number can be used as a base in a logarithm calculation, which is used in the entropy method, all such negative indicators should be "moved" to the positive area without changing the differences among EU countries. Also, zero values of indicators should be avoided.

The adjustment was made by adding the appropriate value to data on indicators for all countries. The calculation of that corrective value was performed using the formula:

$$
\Delta x=\left|x_{\min }\right|+1,
$$

where:

$\Delta x$ is the corrective value,

$x_{\text {min }}$ is the minimum value of the mentioned indicator for all countries in both analysed years.

After these adjustments, the Shannon entropy index is calculated as follows. Firstly, it should be pointed out that the Shannon entropy measures the amount of uncertainty about the event with an appropriate probability distribution. In this paper, mentioned "events" are convergence indicators, and they are marked by $x$. The information gained from the appearance of a certain event is determined by the monotonically decreasing function with the probability $p$, which can be represented by $\log 1 / p=-\log p$. For a series of events $x_{i}$ with probabilities, $p_{i}$ it can be defined that

$$
0 \leq p\left(x_{i}\right) \leq 1, \sum_{i=1}^{n} p\left(x_{i}\right)=1
$$

considering that $x_{i}$ represents a certain convergence indicator for the country $i$, where $i=1,2 \ldots n$.

The entropy measure $H(x)$ is the expected value of this series that can be presented as:

$$
H(x)=-\sum_{i=1}^{n} p\left(x_{i}\right) \log p\left(x_{i}\right)
$$

or

$$
H(x)=\sum_{i=1}^{n} p\left(x_{i}\right) \log _{2} \frac{1}{p\left(x_{i}\right)} .
$$

It should be emphasized that the use of the logarithm function with base 2 implies the measurement of information in bits. 
According to Czyz \& Hauke (2015), the presented formula for calculation of the Shannon entropy has the following characteristics:

1. $H(x) \geq 0$, i.e., it is a positive value;

2. $H(x)$ assumes the value of 0 with $p\left(x_{i=1} 1\right.$ for chosen $i$, indicating the absence of uncertainty among indicators;

3. $H(x)$ assumes the highest value equal to $\log _{2} n$ when all values of $p\left(x_{i}\right)$ are equal for $i=1,2, \ldots n$. The maximum value $H(x)$ means a total uncertainty or disorder of a system.

On the basis of the entropy indicator $H(x)$, the Shannon entropy index $I(x)$ is developed and used as a measure of divergence among EU countries according to the considered convergence indicator $x$. The Shannon entropy index $I(x)$ is calculated as follows:

$$
\begin{aligned}
& I(x)=H(x)_{\max }-H(x)=\log _{2} n-\sum_{i=1}^{n} p\left(x_{i}\right) \log _{2} \frac{1}{p\left(x_{i}\right)} \\
& =\sum_{i=1}^{n} p\left(x_{i}\right) \log _{2}\left[n p\left(x_{i}\right)\right]
\end{aligned}
$$

for $0 \leq I(x) \leq \log _{2} n$,

where $I(x)=0$ shows the total equality, while $I(x)=\log _{2}$ shows maximum inequality.

\subsubsection{Cluster analysis}

An agglomerative hierarchical clustering procedure (HCA) was applied to analyse the practical problem comprehensively. The aim was to classify EU countries concerning their "similarity/dissimilarity". The objects' similarity (in this case, EU countries) refers to how "closely" they are one to each other in terms of a distance measure (Chen et al., 2009). Ward's method was applied as an agglomerative algorithm, usually used when interval-scaled variables are considered (Bacher, 2002).

To reduce the impact of some indicators, regarding the negative values or a larger magnitude of variations, on the clustering results with present particular observed data, the three variables included in the study were standardized using the formula:

$$
z_{i}\left(x_{i}\right)=\frac{x_{i}-\min (X)}{\max (X)-\min (X)}
$$


The use of Ward's method enabled minimizing the total within-cluster variance while between-cluster variance is maximized. The squared Euclidean distance (SED) is used to measure dissimilarity between objects (countries). The complex computational process of the HAC procedure requires performing it by using statistical software. In this respect, IBM SPSS v.20 was used.

One of the first outputs of the IBM SPSS procedure used for examining the convergence process among EU countries - the initial dissimilarity matrix of Ward's method - was used to compare each country's performances with all the others, with the EU average, or a group of countries too. A high value of the distance between two countries means a high dissimilarity, and it can be interpreted as a high divergence, or, in other words, a low convergence between them.

The dissimilarity matrix consists of all SEDs computed for each pair of countries, computed by the following formula:

$$
d\left(Z_{i}, Z_{j}\right)=d_{i j}=\sum_{k=1}^{p}\left(z_{i k}-z_{j k}\right)^{2}=Z_{i}-Z_{j}^{2},
$$

where, in our case:

$i$ and $j$ are the two different countries, including EU-27 (single-clusters),

$p$ - variables $\mathrm{Z}_{1}, \mathrm{Z}_{2}, \mathrm{Z}_{3}$ are the standardized considered indicators of real convergence,

$\mathrm{z}_{i 1}, \mathrm{z}_{i 2}, \mathrm{z}_{i 3}$ are scores of registered data for the county $i$,

$\mathrm{z}_{j 1}, \mathrm{z}_{j 2}, \mathrm{z}_{j 3}$ are scores of registered data for the country $j$.

During the agglomerative process, after every new obtained cluster, all dissimilarities between all of them are re-considered (Bacher, 2002) using the formula:

$$
d_{(p+q), i}^{\text {new }}=\frac{1}{n_{p}+n_{q}+n_{i}} \times\left[\left(n_{p}+n_{i}\right) \times d_{p i}+\left(n_{q}+n_{i}\right) \times d_{q i}-n_{i} \times d_{p q}\right],
$$

where:

$d_{(p+q), i}^{\text {new }}$ is the dissimilarity between the new cluster $(p+q)$ and the cluster $i$, $d_{p i}$ is the dissimilarity between the cluster $p$ and the cluster $i$, $d_{q i}$ is the dissimilarity between the cluster $q$ and the cluster $i$.

\section{Results and Discussion}

Use of the presented methodology enabled calculation of the Shannon entropy index for all real convergence indicators in 2008 and 2020. The advantage of this divergence measure is that its calculation considers the number of EU Member States in mentioned years, without influence on obtained results. Besides comparative analysis at different points 
of time, the divergence among EU countries should be accompanied by the EU average. Parallel analysis of these two values gives a more detailed picture of convergence processes because differences among countries can decrease due to worsening or improving state in most countries, and it is very important to identify the cause of differences. Also, it should be mentioned that the authors took into account that Croatia joined the EU in 2013 and the United Kingdom exited from the EU in 2020 while calculating the Shannon entropy index in 2020.

The first considered real convergence indicator is GDP per capita PPP. Without it, no serious study of real convergence can be imagined. The average value of this indicator and the calculated Shannon entropy index are presented in Figure 1.

Figure 1: Shannon entropy index and EU average for GDP per capita PPP (in 000)

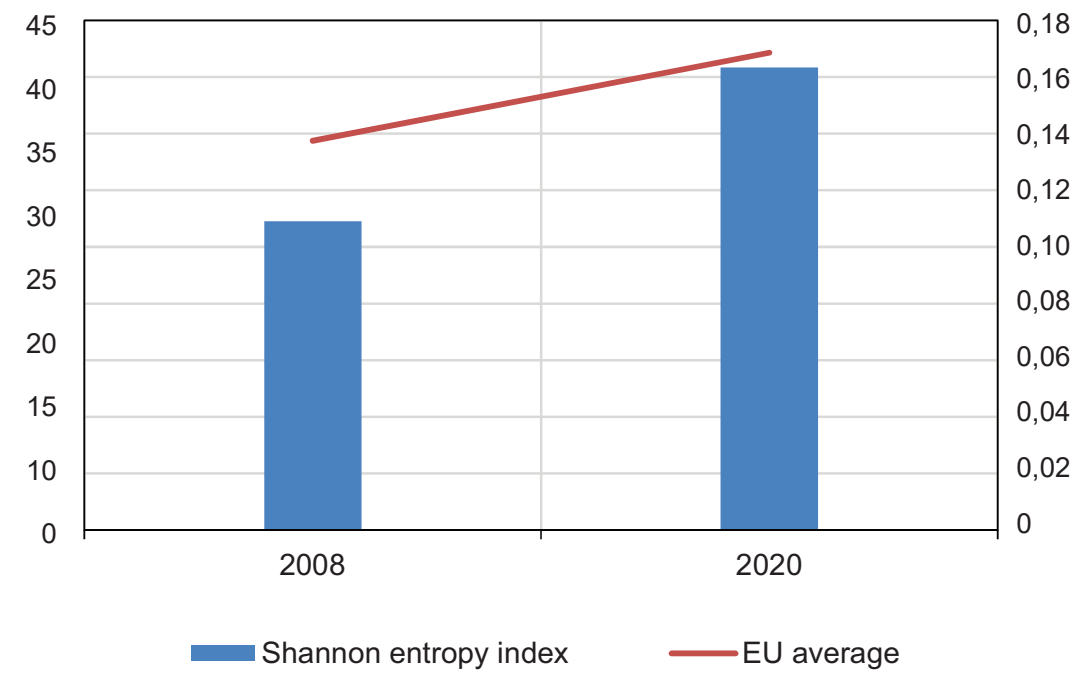

Source: Authors' calculations

The indicators presented in Figure 1 undoubtedly point out that differences are increased, while the average GDP per capita PPP recorded the growth, indicating that the divergence process occurred due to a further increase in the observed indicator across EU economies. To explain such a trend, the differences in the mentioned real convergence indicator in 2008 and 2020 across EU economies are presented in Table 2. 
Table 2: Differences in GDP per capita PPP in 2008 and 2020 across EU economies

\begin{tabular}{|c|c|c|c|c|c|}
\hline Country & $\begin{array}{l}\text { GDP per capita } \\
\text { PPP 2008 } \\
\text { (in 000) }\end{array}$ & $\begin{array}{c}\text { Index } \\
\text { (EU } \\
\text { average) }\end{array}$ & $\begin{array}{l}\text { GDP per capita } \\
\text { PPP 2020 } \\
\text { (in 000) }\end{array}$ & $\begin{array}{c}\text { Index } \\
\text { (EU } \\
\text { average) }\end{array}$ & $\begin{array}{c}\text { Difference } \\
\text { between } 2008 \\
\text { and } 2020 \text { (in \%) }\end{array}$ \\
\hline Austria & 42.77 & 125.61 & 49.52 & 118.21 & 15.77 \\
\hline Belgium & 39.39 & 115.67 & 46.59 & 111.23 & 18.30 \\
\hline Bulgaria & 15.53 & 45.60 & 23.86 & 56.96 & 53.66 \\
\hline Cyprus & - & - & 25.54 & 60.96 & - \\
\hline Czech Republic & 36.32 & 106.65 & 39.22 & 93.61 & 7.98 \\
\hline Croatia & 28.08 & 82.46 & 36.48 & 87.07 & 29.90 \\
\hline Denmark & 42.94 & 126.09 & 51.48 & 122.88 & 19.89 \\
\hline Estonia & 24.44 & 71.78 & 33.71 & 80.48 & 37.93 \\
\hline Finland & 40.69 & 119.48 & 45.47 & 108.55 & 11.77 \\
\hline France & 37.25 & 109.38 & 44.00 & 105.04 & 18.15 \\
\hline Germany & 40.32 & 118.39 & 50.15 & 119.70 & 24.38 \\
\hline Greece & 31.57 & 92.70 & 27.41 & 65.44 & -13.15 \\
\hline Hungary & 22.95 & 67.40 & 33.62 & 80.26 & 46.48 \\
\hline Ireland & 45.33 & 133.12 & 78.26 & 186.82 & 72.65 \\
\hline Italy & 36.00 & 105.71 & 37.27 & 88.96 & 3.53 \\
\hline Latvia & 20.71 & 60.83 & 28.42 & 67.83 & 37.17 \\
\hline Lithuania & 22.56 & 66.24 & 34.50 & 82.35 & 52.95 \\
\hline Luxembourg & 91.97 & 270.07 & 105.39 & 251.58 & 14.59 \\
\hline Malta & 28.17 & 82.74 & 45.63 & 108.93 & 61.96 \\
\hline Netherlands & 46.20 & 135.68 & 54.16 & 129.28 & 17.22 \\
\hline Poland & 19.36 & 56.86 & 32.57 & 77.76 & 68.22 \\
\hline Portugal & 26.36 & 77.40 & 31.34 & 74.81 & 18.90 \\
\hline Romania & 17.41 & 51.14 & 26.90 & 64.21 & 54.46 \\
\hline Slovakia & 24.35 & 71.50 & 34.30 & 81.89 & 40.88 \\
\hline Slovenia & 29.98 & 88.03 & 35.38 & 84.46 & 18.04 \\
\hline Spain & 32.96 & 96.79 & 38.00 & 90.72 & 15.30 \\
\hline Sweden & 41.77 & 122.68 & 50.83 & 121.36 & 21.70 \\
\hline United Kingdom & 37.28 & 109.47 & - & - & - \\
\hline
\end{tabular}

Source: Authors' calculations based on data extracted from World Economic Outlook Database (April 2020 Edition), [online database] 
It is interesting to emphasize that, according to data from Table 2, all the countries recorded higher GDP per capita PPP in 2020 than in 2008, except Greece, which was severely hit by the pandemic crisis. This trend explains why the EU average was much higher in 2020 than in 2008. Considering that the rate of increase varied significantly across EU economies, it is not surprising that the results of the entropy method indicated an increase in differences in comparison to 2020. It should be noted that Austria, Belgium, Denmark, Finland, France, Germany, Ireland, Luxembourg, the Netherlands and Sweden had above-average GDP per capita PPP in both 2008 and 2020. In 2008, the Czech Republic and Italy had slightly higher GDP per capita PPP than the EU average, but these countries have been hit by the pandemic crisis (especially Italy), resulting in the above-average value of the mentioned indicator in 2020 .

On the other hand, Malta had above-average GDP per capita PPP in 2020, although it was not the case in 2008. Although CEE and SEE countries had below-average values of this indicator, the catching-up process to EU average is evident (except in the Czech Republic and Slovenia), since the value of their GDP per capita PPP in 2020 was much closer to the EU average than in 2008. Considering data from Table 2, it could be concluded that there is some convergence process within this group of countries, as was suggested by Cieslik and Wcislik (2020).

The next real convergence indicator used in this study is the unemployment rate, one of the indicators most commonly used in convergence analysis. The value of the Shannon entropy index and the EU average are presented in Figure 2.

Figure 2 points out that differences across EU economies regarding this real convergence indicator were much higher in 2020 compared to 2008, and that the EU average had increased. Such a trend of presented indicators shows that in most countries, this indicator had increased, considering that the labour market reacted to the crisis in 2009 immediately by higher unemployment (Mihaela, 2013). However, the higher divergence among EU countries results from considerable differences in the growth rate of this indicator, as in the previous case. Durkalic et al. (2019) suggested that the divergences in the unemployment rate started to grow after the global financial crisis due to differences in responses to the crisis, the impact of the crisis, and significant imbalances on the labour market in the NMS and some of the OMS. For a detailed explanation of the results, the differences from the EU average in 2008 and 2020 are calculated. The results are presented in Table 3. 


\section{Figure 2: Shannon entropy index and EU average for unemployment rate (in \%)}

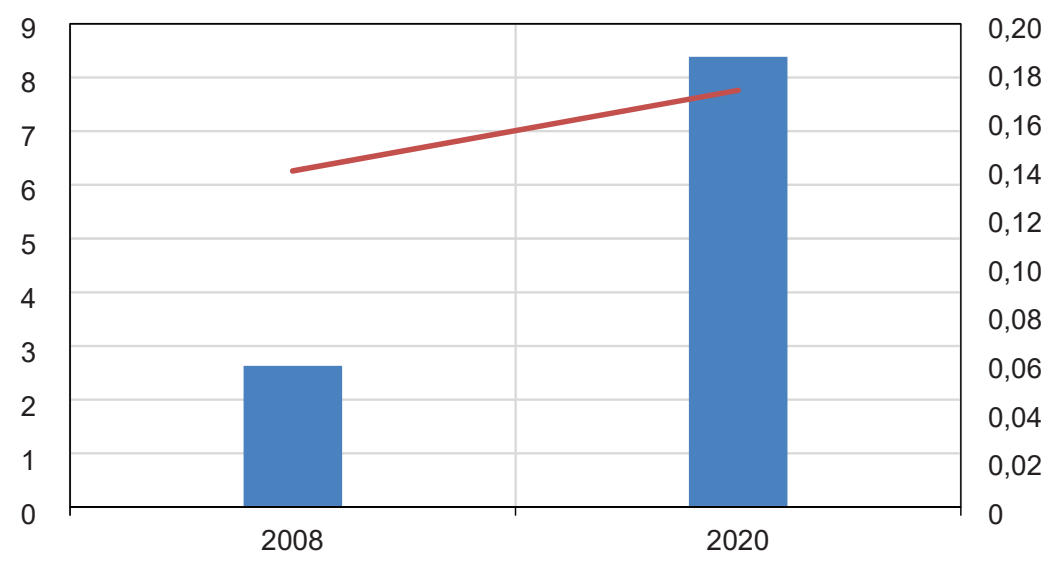

Shannon entropy index

EU average

Source: Authors' calculations

The first glance at Table 3 indicates a larger number of countries where the unemployment rate was above the EU average in 2008 than in 2020, and most of them were Western European countries. However, in 2020, several countries, such as Croatia, Greece, Ireland, Italy, Portugal and Spain, had a considerably higher unemployment rate than the EU average, which significantly contributed to the increasing Shannon entropy index. It can be explained, as was suggested by Mayer and Schnabl (2020), by the fact that the Southern EMU countries have been hit stronger by the pandemic crisis than the Northern countries because they rely significantly on tourism and have a higher share of small and medium-sized enterprises than the northern ones, their competitiveness declining even further. Besides them, France, Romania and Sweden also recorded a two-digit unemployment rate. It is also interesting to note that some countries succeeded in recording a lower unemployment rate in 2020 than in 2008, notably Germany, Hungary, Malta and Slovakia. Hungary recorded the lowest unemployment rate among CEE and SEE countries, while Germany was the best performer in that sense if all EU countries are considered.

The last considered indicator is the current account balance, which is a very important indicator, especially during crisis times. In that sense, the Shannon entropy index and the EU average for this indicator are presented in Figure 3. 
Table 3: Differences in unemployment rate in 2008 and 2020 across EU economies

\begin{tabular}{|c|c|c|c|c|c|}
\hline Country & 2008 & $\begin{array}{l}\text { Index (EU } \\
\text { average) }\end{array}$ & 2020 & $\begin{array}{l}\text { Index (EU } \\
\text { average) }\end{array}$ & $\begin{array}{c}\text { Difference } \\
\text { between } 2008 \\
\text { and } 2020 \text { (in \%) }\end{array}$ \\
\hline Austria & 4.09 & 65.38 & 5.50 & 58.43 & 34.41 \\
\hline Belgium & 6.97 & 111.31 & 7.30 & 77.55 & 4.78 \\
\hline Bulgaria & 5.66 & 90.49 & 8.00 & 84.99 & 41.24 \\
\hline Croatia & - & - & 11.50 & 122.17 & - \\
\hline Cyprus & 3.65 & 58.32 & 8.82 & 93.74 & 141.75 \\
\hline Czech Republic & 4.38 & 70.00 & 7.50 & 79.67 & 71.19 \\
\hline Denmark & 3.72 & 59.39 & 6.50 & 69.05 & 74.87 \\
\hline Estonia & 5.46 & 87.15 & 6.00 & 63.74 & 9.99 \\
\hline Finland & 6.43 & 102.65 & 8.27 & 87.80 & 28.64 \\
\hline France & 7.46 & 119.16 & 10.40 & 110.46 & 39.42 \\
\hline Germany & 7.38 & 117.96 & 3.89 & 41.28 & -47.37 \\
\hline Greece & 7.75 & 123.82 & 22.33 & 237.19 & 188.10 \\
\hline Hungary & 7.82 & 124.88 & 5.40 & 57.31 & -30.97 \\
\hline Ireland & 6.80 & 108.64 & 12.11 & 128.64 & 78.07 \\
\hline Italy & 6.74 & 107.72 & 12.70 & 134.91 & 88.37 \\
\hline Latvia & 7.74 & 123.69 & 8.00 & 84.99 & 3.33 \\
\hline Lithuania & 5.83 & 93.10 & 8.90 & 94.55 & 52.74 \\
\hline Luxembourg & 4.14 & 66.18 & 7.72 & 81.98 & 86.31 \\
\hline Malta & 5.98 & 95.46 & 5.00 & 53.12 & -16.32 \\
\hline Netherlands & 3.66 & 58.52 & 6.50 & 69.05 & 77.45 \\
\hline Poland & 7.12 & 113.74 & 9.92 & 105.37 & 39.33 \\
\hline Portugal & 7.55 & 120.66 & 13.94 & 148.09 & 84.59 \\
\hline Romania & 5.54 & 88.58 & 10.10 & 107.29 & 82.18 \\
\hline Slovakia & 9.59 & 153.25 & 8.02 & 85.16 & -16.43 \\
\hline Slovenia & 4.40 & 70.30 & 9.00 & 95.61 & 104.55 \\
\hline Spain & 11.25 & 179.66 & 20.80 & 220.97 & 84.98 \\
\hline Sweden & 6.17 & 98.53 & 10.06 & 106.91 & 63.19 \\
\hline United Kingdom & 5.725 & 91.47 & - & - & - \\
\hline
\end{tabular}

Source: Authors' calculations based on data extracted from World Economic Outlook Database (April 2020 Edition), [online database] 


\section{Figure 3: Shannon entropy index and EU average for current account balance (\% of GDP)}

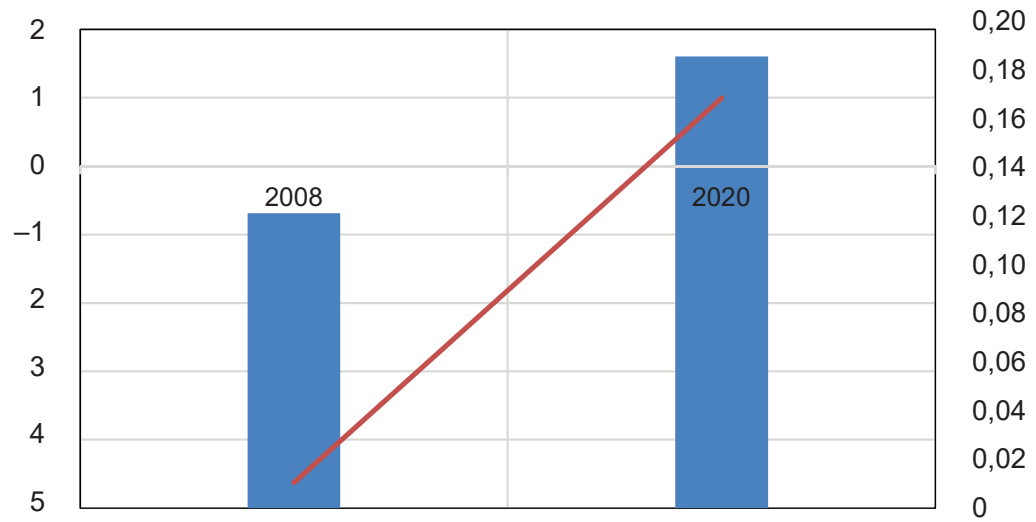

Shannon entropy index —EU average

Source: Authors' calculations

The results presented in Figure 3 indicate that, in contrast to the global financial crisis characterized by a significant average deficit at the EU level and relatively lower differences across EU countries, the pandemic crisis resulted in much more pronounced differences and low average surplus. This means that most countries faced with high deficits in 2008 had changed their trade position from net importers to net exporters by 2020 . However, the value of the current account balance varied considerably across EU members. Table 4 presents the current account balance in 2008 and 2020 across EU economies and comparisons to the EU average to enable deeper analysis of changes between the emergences of the observed crises.

The data in Table 4 show that many EU economies recorded high current account deficits, especially Bulgaria, Cyprus, Greece, Latvia, Lithuania, Portugal and Romania, where two-digit deficits were recorded. On the other hand, Austria, Denmark, Finland, Germany, Luxembourg, the Netherlands and Sweden were the rare countries achieving a current account surplus. It is interesting to note that all CEE and SEE economies recorded current account deficits. It can be explained by a sudden stop in demand in these countries, which contracted current transactions and a reduced the inflow of FDI. In contrast to the global financial crisis, the pandemic crisis had a considerably different effect on current account balance across EU economies. Most of them recorded current account surpluses and those that recorded deficits, did not face deficits as high as in 2008. Several countries, such as Bulgaria, Ireland, Italy, Lithuania, Malta, Slovenia and Spain, managed to balance their current account or recorded a relatively high surplus in 2020 . 
Table 4: Differences in current account balance in 2008 and 2020 across EU economies

\begin{tabular}{|c|c|c|c|c|c|}
\hline Country & 2008 & $\begin{array}{c}\text { Difference } \\
\text { in comparison } \\
\text { to EU average } \\
\text { (in \%) }\end{array}$ & 2020 & $\begin{array}{c}\text { Difference } \\
\text { in comparison } \\
\text { to EU average } \\
\text { (in \%) }\end{array}$ & $\begin{array}{c}\text { Difference } \\
\text { between } 2008 \\
\text { and } 2020 \text { (in \%) }\end{array}$ \\
\hline Austria & 4,49 & 9,14 & 1,90 & 1,41 & $-2,59$ \\
\hline Belgium & $-1,01$ & 3,65 & $-0,70$ & $-1,19$ & 0,30 \\
\hline Bulgaria & $-22,09$ & $-17,44$ & 1,66 & 1,18 & 23,76 \\
\hline Croatia & - & - & $-3,99$ & $-4,47$ & - \\
\hline Cyprus & $-14,74$ & $-10,09$ & $-8,29$ & $-8,77$ & 6,45 \\
\hline Czech Republic & $-1,87$ & 2,78 & $-2,06$ & $-2,54$ & $-0,19$ \\
\hline Denmark & 2,92 & 7,57 & 4,81 & 4,33 & 1,90 \\
\hline Estonia & $-8,65$ & $-3,99$ & $-2,69$ & $-3,17$ & 5,96 \\
\hline Finland & 2,54 & 7,20 & $-3,48$ & $-3,96$ & $-6,02$ \\
\hline France & $-0,70$ & 3,96 & $-0,73$ & $-1,21$ & $-0,03$ \\
\hline Germany & 5,69 & 10,34 & 6,58 & 6,10 & 0,89 \\
\hline Greece & $-14,48$ & $-9,83$ & $-6,50$ & $-6,98$ & 7,98 \\
\hline Hungary & $-6,76$ & $-2,10$ & $-0,12$ & $-0,61$ & 6,63 \\
\hline Ireland & $-6,24$ & $-1,59$ & 6,27 & 5,78 & 12,50 \\
\hline Italy & $-2,80$ & 1,86 & 3,05 & 2,57 & 5,85 \\
\hline Latvia & $-12,33$ & $-7,67$ & $-2,16$ & $-2,64$ & 10,17 \\
\hline Lithuania & $-13,61$ & $-8,95$ & 6,01 & 5,53 & 19,62 \\
\hline Luxembourg & 7,57 & 12,23 & 3,96 & 3,48 & $-3,62$ \\
\hline Malta & $-1,05$ & 3,60 & 3,33 & 2,85 & 4,38 \\
\hline Netherlands & 4,97 & 9,62 & 9,01 & 8,52 & 4,04 \\
\hline Poland & $-6,71$ & $-2,06$ & 0,16 & $-0,32$ & 6,87 \\
\hline Portugal & $-11,83$ & $-7,18$ & 0,28 & $-0,20$ & 12,12 \\
\hline Romania & $-11,53$ & $-6,87$ & $-5,50$ & $-5,99$ & 6,02 \\
\hline Slovakia & $-6,36$ & $-1,71$ & $-2,99$ & $-3,47$ & 3,37 \\
\hline Slovenia & $-5,32$ & $-0,67$ & 0,85 & 0,36 & 6,17 \\
\hline Spain & $-8,90$ & $-4,25$ & 2,18 & 1,69 & 11,08 \\
\hline Sweden & 7,82 & 12,47 & 2,21 & 1,73 & $-5,61$ \\
\hline United Kingdom & $-3,931$ & 0,72 & - & - & - \\
\hline
\end{tabular}

Source: Authors' calculations based on data extracted from World Economic Outlook Database (April 2020 Edition), [online database] 
The derived values are summarized in Figure 4 to compare the value of the Shannon entropy index for all observed indicators in 2008 and 2020.

\section{Figure 4: Shannon entropy index for all observed indicators in 2008 and 2020}

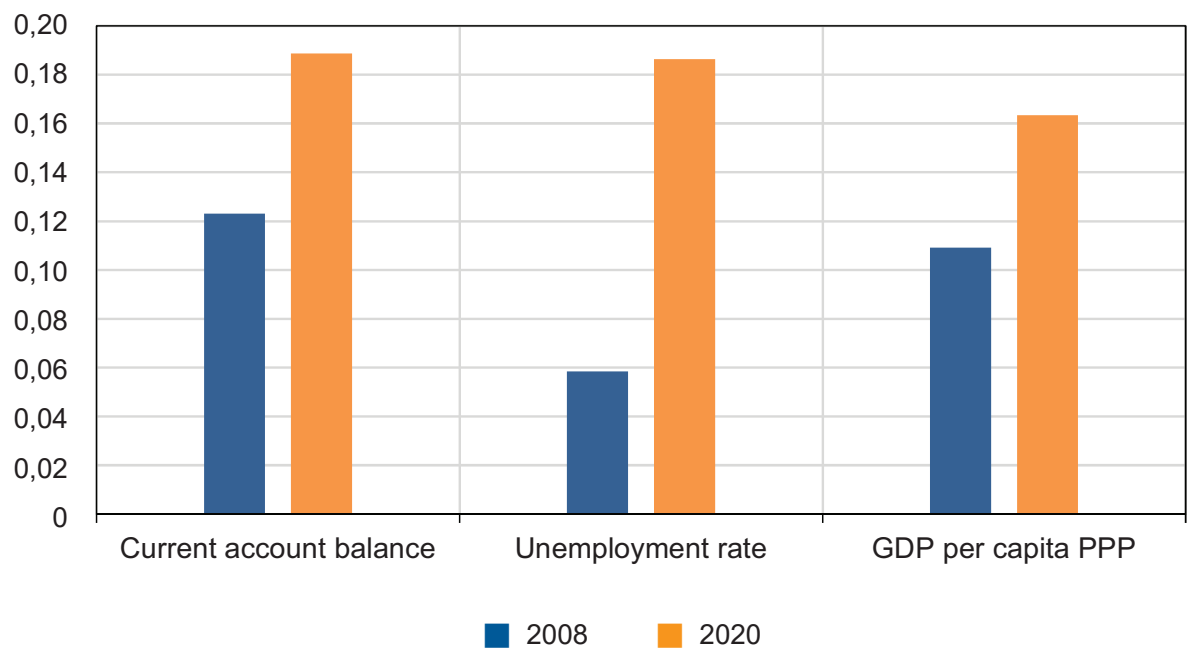

Source: Authors' calculations

Figure 4 indicates that the most pronounced differences between the global financial and pandemic crises were recorded regarding the unemployment rate, while differences in the value of the Shannon entropy index for 2008 and 2020 for the remaining two indicators were almost the same. However, if 2020 is considered, the most pronounced differences across EU countries are recorded for current account balance, while the divergence in the unemployment rate is slightly lower. The differences in GDP per capita PPP were the lowest among the observed real convergence indicators in 2020. It is interesting to note that divergence in the mentioned indicator was much more pronounced than those regarding the unemployment rate in 2008.

Besides the entropy method, cluster analysis was employed as a complementary research tool, aiming to obtain a basis for the formulation of policy implications. The cluster analysis was performed only for 2020; based on the proximity matrix of squared Euclidean distances computed in the first stage of the hierarchical cluster algorithm using Ward's methods, Slovenia and France appear to be the closest countries to the EU average (Table 5). 
Table 5: Rankings of countries by dissimilarities in comparison to EU average 2020 (initial squared Euclidian distances between countries, rescaled)

\begin{tabular}{l|c|l|c}
\hline Country & $\begin{array}{c}\text { Initial squared } \\
\text { Euclidian distances } \\
\text { (EU-27) }\end{array}$ & \multicolumn{1}{|c|}{ Country } & $\begin{array}{c}\text { Initial squared } \\
\text { Euclidian distances } \\
\text { (EU-27) }\end{array}$ \\
\hline Slovenia & 0.008 & Estonia & 0.079 \\
\hline France & 0.008 & Malta & 0.086 \\
\hline Poland & 0.015 & Denmark & 0.100 \\
\hline Belgium & 0.021 & Lithuania & 0.112 \\
\hline Sweden & 0.022 & Croatia & 0.122 \\
\hline Czech Republic & 0.037 & Romania & 0.156 \\
\hline Slovakia & 0.055 & Germany & 0.223 \\
\hline Italy & 0.058 & Cyprus & 0.259 \\
\hline Finland & 0.058 & Netherlands & 0.289 \\
\hline Latvia & 0.058 & Ireland & 0.329 \\
\hline Hungary & 0.060 & Spain & 0.394 \\
\hline Austria & 0.060 & Luxembourg & 0.649 \\
\hline Bulgaria & 0.061 & Greece & 0.687 \\
\hline Portugal & 0.078 & Median distance & 0.078 \\
\hline
\end{tabular}

Source: Elaborated by the authors based on IBM SPSS output

Table 5 also indicates the interesting trend of the real convergence process in the EU regarding the position of the New Member States (NMS) and Old Member States (OMS). Namely, most NMS are near or relatively near the EU average. Seven of them even have an initial squared Euclidian distance lower than the median value. Only Estonia, Malta, Croatia, Romania and Cyprus are relatively far from the EU average, but not as far as the five OMS positioned at the end of the rankings (the Netherlands, Ireland, Spain, Luxemburg and Greece).

Nevertheless, the data in Table 5 give just the first insight into the position of Member States concerning the EU average. However, for detailed insight into characteristics of EU economies, the cluster analysis was performed using the HAC algorithm with Ward's method, and the results are presented in Figure 5. 
Figure 5: Dendrogram obtained by hierarchical clustering (using Ward's method)

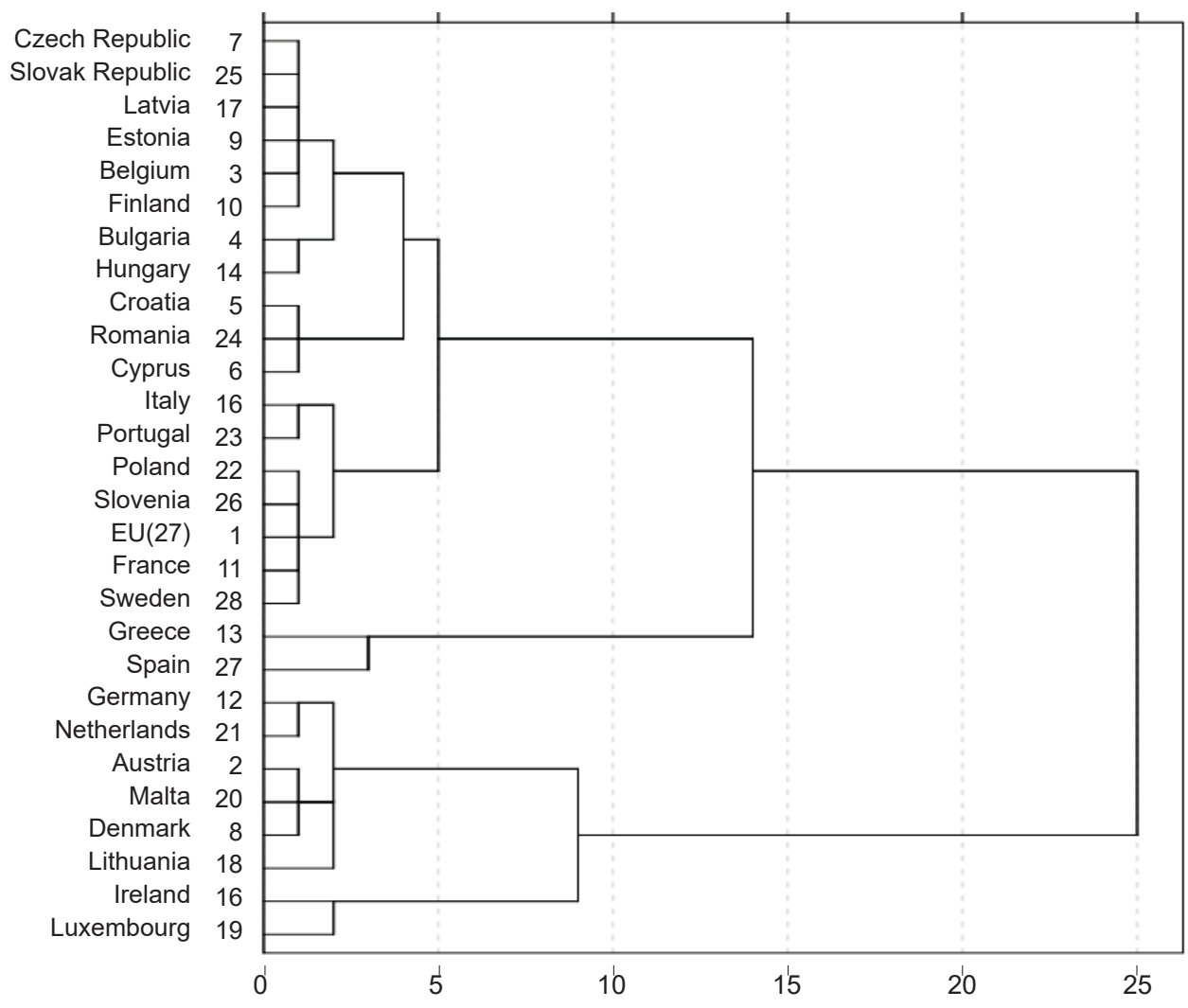

Source: Performed by the authors - IBM SPSS output

Besides EU countries, the EU average is also included as one of the considered cases to define the group of countries that are the most similar to the EU average. The three-cluster solution was chosen to obtain a low rescaled distance of 10 and a sufficient number of clusters. The average values of observed indicators are calculated and presented in Table 5 to access the main characteristics of derived clusters.

The presented average cluster values from Table 6 give a rough picture of the clusters' characteristics and the main differences among them. According to the results presented in Table 6, the main characteristics of the formed clusters are derived and presented in Table 7. The characteristics are derived based on a comparison of cluster averages with the EU average. 
Table 6: Average values of observed indicators for derived clusters

\begin{tabular}{l|c|c|c|c}
\hline Cluster & Number of countries & GDP & UNEMP & CAB \\
\hline Cluster 1 & $\begin{array}{r}18, \\
\text { including EU-27 }\end{array}$ & 35,985 & 9.130 & -1.334 \\
\hline Cluster 2 & 8 & 58,635 & 7.015 & 5.234 \\
\hline Cluster 3 & 2 & 32,708 & 21.565 & -2.160 \\
\hline EU average & 27 & 42,223 & 9.414 & 0.483 \\
\hline
\end{tabular}

Source: Authors' calculations

Table 7: Structure of clusters and their characteristics

\begin{tabular}{l|l|l|l|l}
\hline Cluster & \multicolumn{1}{|c|}{ Countries } & GDP & \multicolumn{1}{c|}{ UNEMP } & \multicolumn{1}{c}{ CAB } \\
\hline Cluster 1 & $\begin{array}{l}\text { EU-27, Slovenia, Poland, Czech } \\
\text { Republic, Slovakia, Latvia, Estonia, } \\
\text { Bulgaria, Hungary, Croatia, Romania, } \\
\text { and Cyprus, France, Italy, Portugal, } \\
\text { Sweden, Finland and Belgium }\end{array}$ & Low & $\begin{array}{l}\text { Close to EU } \\
\text { average }\end{array}$ & Deficit \\
\hline Cluster 2 & $\begin{array}{l}\text { Germany, Netherlands, Austria, Malta, } \\
\text { Denmark, Lithuania, Ireland and } \\
\text { Luxembourg }\end{array}$ & High & Low & Surplus \\
\hline Cluster 3 & Spain and Greece & Low & Very high & Deficit \\
\hline
\end{tabular}

Source: According to the authors' calculations

From the characteristics of EU economies presented in Table 7, it can be concluded that countries in Cluster 2 have the most favourable position. They have a high GDP per capita PPP, low unemployment rate, and current account surplus. Except for Denmark, this cluster consists of EMU countries, and most of them are small open economies. In a somewhat less favourable position are the majority of EU economies dedicated to Cluster 1 . The countries from this cluster have the most similar characteristics to the EU average, which is also approved by positioning the EU average in this cluster. Finally, Cluster 3 consists of two countries that were mostly hit by the pandemic crisis. They struggled to stabilize their public finances and finance growth and employment (Despotovic and Durkalic, 2017). 


\section{Policy Implications}

The results of the empirical analysis suggest a considerably different, cluster-dependent approach to economic policy measures. Accordingly, the economies from Cluster 2 demonstrate a high degree of resilience when faced with the negative effects of the current pandemic. Like in other countries, although their governments had to undertake large fiscal stimulation packages to prevent much serious economic recession, these measures do not appear to worsen the value of the real convergence indicators. Having relatively stable and favourable economic conditions at the onset of the ongoing crisis, these countries could respond to the shock using much more aggressive stimulation measures. Among many examples, one can mention the state-sponsored work-sharing schemes aimed at saving jobs implemented in Germany (so-called Kurzarbeit). This social insurance programme effectively kept employment stable during the 2008 economic crisis, but its importance in times of pandemic seems to be much more profound.

However, it must be stressed that these measures inevitably deteriorate the budget balance and increase government debt. Although these indicators represent the domain of the nominal convergence, they affect the employment dynamics and economic growth, as well as the current account balance, suggesting the implementation of a much more complex approach to economic policy management. Of course, pursuing fiscal policies aimed at achieving prudent fiscal positions and debt sustainability is particularly important and should be implemented when economic conditions allow.

The countries in Cluster 3 (Spain and Greece) are faced with significant deterioration of all real convergence indicators. These economies had already been in an unfavourable position due to high unemployment rates and current account deficits, which are seriously worsened due to the pandemic. Bearing in mind that these countries rely significantly on tourism revenues, implementing effective policy measures directed to employment preservation and support of the tourism sector is of utmost importance. The role of employment and social services in supporting workers and employers is very significant and should be based on introducing some forms of flexicurity. This model could improve the flexibility of the labour market, but during the pandemic crisis, it should be complemented by programmes aimed at achieving employment security, especially in contact-intensive activities which are particularly hit by the crisis. In the medium term, the combination of different active labour market policies directed to employability improvement should also be used. However, the key limitation for applying these measures lies in the chronic public finance misbalance in these countries, narrowing the space for more determined action aimed at unemployment rate reduction. 
Cluster 1 is rather heterogeneous and comprises the New EU Member States (which joined the EU in 2004, 2007 and 2013) and the Old Member States, among which there are several European Monetary Union (EMU) members. The lack of monetary sovereignty in EMU members limits the space for implementing monetary policy measures that could boost economic activity and employment without the risk of overreaching the inflation targets. This is a markedly serious obstacle in economies severely hit by the pandemic, such as Italy and Belgium. However, independent monetary policies can be implemented in most of the countries in Cluster 1. Given the very low interest rates, central banks in those countries should turn to unconventional monetary policy tools, such as largescale asset purchases. The key importance of these tools is reflected in stimulating private investment activity to boost growth in sectors with the largest potential regarding employment promotion.

Bearing in mind the uncertain prospects of the current pandemic crisis, the economic policy approach for all countries should generally be based on expansionary fiscal policy, mainly on a discretionary basis, along with a frequent assessment of the budget balance stance. These measures should tackle aggregate demand, stimulate business activity and boost aggregate supply to prevent a significant decrease in the GDP per capita. Finally, when the pandemic is over, the governments of all the countries, especially in Clusters 1 and 3, should exploit all capacities to boost economic growth to reach the pre-crisis GDP levels as fast as possible. More importantly, that growth should be dynamic enough and sustainable to improve the real convergence process.

\section{Conclusion}

The COVID-19 pandemic represents a public health crisis, testing the EU's collective capacity to respond to such a devasting economic shock and ensure convergence among EU economies. The EU leaders find themselves faced with considerable imbalances in the epidemic conditions because the revenues of economic entities operating in EU economies have registered a significant drop. On the other hand, their expenditures regarding communal services, business premises rent, salaries, taxes and suchlike have remained almost the same. Such a situation can lead, if it is not well handled, to mass bankruptcies, unemployment growth and the occurrence of a sovereign debt crisis. Hence, it is not surprising that the ECB and national central banks have made significant efforts to add additional liquidity, aiming to support companies and banks to overcome a sharp drop in income and reduce the number of bankruptcies and jobs closed.

The vulnerability of EU economies depends on many factors, such as the GDP structure, the share of workers with permanent contracts in total employment, the level of the shadow economy, stability of public finances and ability of governments to implement efficient 
recovery measures. Keeping in mind that the EU Member States are still very different in these respects, it is realistic to expect that the real convergence process, which is a crucial driver of the EU's sustainable functioning, will be hampered.

The entropy method employed in this study enabled drawing of some general conclusions on real convergence processes in the EU. The results pointed out that differences in all the observed indicators in 2020 were higher than in 2008 . The most pronounced divergence process is recorded regarding the current account balance, followed by the unemployment rate, where differences were slightly lower. Finally, the differences in GDP per capita PPP were the lowest but still higher than in 2008.

The cluster analysis resulted in 3 clusters. The EU countries in the first cluster (which is the most numerous) have similar performance characteristics as the EU. Those in Cluster 2 are the best performers, and those from the third cluster are the most affected by the crisis. The differences among EU countries are still present, and the European Commission should adjust measures to conditions in each particular group of countries to ensure real convergence in the future.

The COVID-19 crisis will raise fundamental questions about how to manage real convergence processes. The current crisis will lead to a deepening of economic differences between the NMS and OMS and between the Northern and the Southern economies. The Southern EU member states will be more affected economically, while the Northern members, especially the old ones, will emerge from the crisis faster and become even stronger economically.

The emergence of the pandemic has put the governments and institutions of the European Union into chaos. Each EU country has introduced a different set of recovery measures, which has resulted in mixed economic results. Coordinated and comprehensive action is the essence of the EU future and, according to that, the most efficient way to overcome the crisis and narrow the gaps among national economies is facing recession together. Taken together, the EU is the strongest economic bloc in the world and can decisively shape economic policy in the future.

\section{References}

Albu, L. L. (2012). Structural Convergence in European Union. Annals-Economy Series, Constantin Brancusi University, Faculty of Economics, 4, 1-10.

Alcidi, C., Núñez Ferrer, J., Di Salvo, M., et al. (2018). Income Convergence in the EU: A Tale of Two Speeds. CEPS Commentary, 9, 1-7.

Arce, Ó., Kataryniuk, I., Marín, P., et al. (2020). Thoughts on the Design of a European Recovery Fund. Madrid Banco de España. Occasional Paper No. 2014, https://doi.org/10.2139/ssrn.3611597 
Bacher, J. (2002). Cluster Analysis. Script. Nuremberg. Available at: https://www.clusteranalyse.net/ sonstiges/zaspringseminar2002/lecturenotes.pdf

Bisciari, P., Essers, D., Vincent, E. (2020). Does the EU Convergence Machine Still Work, and How will the Covid-19 Crisis Impact It? SUERF. Policy Note Issue No. 172. Available at: https://www.suerf.org/policynotes/14129/ does-the-eu-convergence-machine-still-work-and-how-will-the-covid-19-crisis-impact-it

Cieślik, A., Wciślik, D. R. (2020). Convergence among the CEE-8 Economies and Their Catch-up Towards the EU-15. Structural Change and Economic Dynamics, 55, 39-48, https://doi. org/10.1016/j.strueco.2020.07.006

Coutinho, L., Turrini, A. (2020). Real Convergence Across the Euro Area. Intereconomics, 55(5), 301-311, https://doi.org/10.1007/s10272-020-0920-2

Czyż, T., Hauke, J. (2015). Entropy in Regional Analysis. Quaestiones Geographicae, 34(4), 69-78, https://doi.org/10.1515/quageo-2015-0037

Despotović, D., Durkalić, D. (2017). Analysis of Budget Deficit in the Candidate Countries for EU Membership. Serbian Journal of Management, 12(2), 237-253, https://doi.org/10.5937/ sjm12-14122

Diaz del Hoyo, J. L., Dorrucci, E., Heinz, F. F., et al. (2017). Real Convergence in the Euro Area: A Longterm Perspective. Frankfurt European Central Bank. ECB Occasional Paper Series No. 203.

Durkalić, D., Fedajev, A., Furtula, S., et al. (2019). The Measurement of Real Convergence in the EU-28 by Using the Entropy Method 1. Ekonomicky Casopis, 67(7), 698-724.

Ferreiro, J., Gálvez, C., Gómez, C., et al. (2017). Economic Crisis and Convergence in the Eurozone Countries. Panoeconomicus, 64(2), 223-244, https://doi.org/10.2298/pan1702223f

IMF (2020). World Economic Outlook Database (April 2020 Edition). Washington, D.C.: IMF. Available at: https://www.imf.org/external/pubs/ft/weo/2020/01/weodata/index.aspx

König, M., Winkler, A. (2020). COVID-19 and Economic Growth: Does Good Government Performance Pay Off? Intereconomics, 55(4), 224-231, https://doi.org/10.1007/ s10272-020-0906-0

Malliaris, A. G., Malliaris, M. (2020). The Impact of the Twin Financial Crises. Journal of Policy Modeling, 42(4), 878-892, https://doi.org/10.1016/j.jpolmod.2020.03.011

Mayer, T., Schnabl, G. (2020). Post-COVID-19 EMU: Economic Distancing by Parallel Currencies. Intereconomics, 55(6), 387-391, https://doi.org/10.1007/s10272-020-0939-4

Mihaela, B. S. (2013). Improvements in Assessing the Forecasts Accuracy-a Case Study for Romanian Macroeconomic Forecasts. Serbian Journal of Management, 8(1), 53-65, https://doi.org/10.5937/sjm8-3235

Młynarzewska-Borowiec, I. (2017). Neoclassical and Technological Catching-up as the Channels of the Real Convergence Process in the European Union. International Journal of Business and Economic Sciences Applied Research (IJBESAR), 10(2), 7-18, https://doi.org/10.25103/ ijbesar.102.01

Simionescu-Bratu, M. (2014) The Economic Convergence in European Union Based on Concentration and Entropy Approach. EuroEconomica, 33(1), 31-42. 